\title{
The bHLH protein PTF1-p48 is essential for the formation of the exocrine and the correct spatial organization of the endocrine pancreas
}

\author{
Andrea Krapp, ${ }^{1,3,4}$ Martin Knöfler, ${ }^{1,3,5}$ Birgit Ledermann, $^{2}$ Kurt Bürki, ${ }^{2}$ Catherine Berney, ${ }^{1}$ \\ Nicole Zoerkler, ${ }^{1}$ Otto Hagenbüchle, ${ }^{1}$ and Peter K. Wellauer ${ }^{1,6}$ \\ ${ }^{1}$ Swiss Institute for Experimental Cancer Research, CH-1066 Epalinges, Switzerland; '2Embryonic Stem Cell Unit, N ovartis, \\ CH-4002 Basel, Switzerland
}

\begin{abstract}
We have generated a mouse bearing a null allele of the gene encoding basic helix-loop-helix (bHLH) protein p48, the cell-specific DNA-binding subunit of hetero-oligomeric transcription factor PTF1 that directs the expression of genes in the exocrine pancreas. The null mutation, which establishes a lethal condition shortly after birth, leads to a complete absence of exocrine pancreatic tissue and its specific products, indicating that p48 is required for differentiation and/or proliferation of the exocrine cell lineage p48 is so far the only developmental regulator known to be required exclusively for committing cells to an exocrine fate. The hormone secreting cells of all four endocrine lineages are present in the mesentery that normally harbors the pancreatic organ until day 16 of gestation. Toward the end of embryonic life, cells expressing endocrine functions are no longer detected at their original location but are now found to colonize the spleen, where they persist in a functional state until postnatal death of the organism occurs. These findings suggest that the presence of the exocrine pancreas is required for the correct spatial assembly of the endocrine pancreas and that, in its absence, endocrine cells are directed by default to the spleen, a site that, in some reptiles, harbors part of this particular cellular compartment.
\end{abstract}

[Key Words: Genetics; gene inactivation; transcription factor; bHLH protein; morphogenesis; pancreas; mouse]

Received June 4, 1998; revised version accepted September 30, 1998.

The mammalian pancreas develops by fusion of dorsal and ventral primordia that origi nate from an evagination of the foregut early during development. Both the endocrine and exocrine portions of the gland differentiate from a common pool of endodermal progenitor cells (Pictet and Rutter 1972; Le Douarin 1988). The exocrine acinar cells secrete digestive enzymes into the gastrointestinal tract, while the four types of endocrine islet cells are specialized for the synthesis of different hormones. Isl et cell-specific differentiation has been studied extensively in rodents and found to requi re the action of genes encoding homeotic proteins Pdx-1 and Isl-1. Pdx-1 (previously termed Ipf-1), the ortholog of the XIHbox8 protein of the frog (Wright et al. 1988), is transiently expressed in all pancreatic cells as well as in the epithelial layer of the duodenal mucosa during embryogenesis (Leonard et al. 1993; Ohlsson et al. 1993; Jonsson et al.

\footnotetext{
${ }^{3}$ These authors contributed equally to this work.

Present addresses ${ }^{4}$ Department of Microbiology and Genetics, Centre Médical Universitaire, University of Geneva, CH-1211 Genève 4, Switzerland; 5 Department of Obstetrics and Gynecology, University of $\mathrm{Vi}$ enna, A-1090 Vienna, Austria.

${ }^{6} \mathrm{C}$ orresponding author.

E-MAIL Peter.Wellauer@isrec.unil.ch; FAX 4121 652-6933.
}

1994; Miller et al. 1994). As development proceeds, Pdx-1 becomes progressively confined to endocrine $\beta$ cells, where it plays a critical role in the transcriptional regulation of the insulin gene (Ohlsson 1993; Guz 1995). M ice carrying a null allele of the gene encoding this protein do not form a pancreatic gland even though the primordi a are formed and the dorsal organ undergoes some limited proliferation (Jonsson 1994; Offield 1996). In addition, the duodenum displays a local absence of epithelial lining (Offield 1996). These observations support a model by which Pdx-1 is expressed in distinct compartments of an endodermal foregut domain, one that differentiates into duodenal epithelium and one that specifies dorsal and ventral pancreas. The fact that both endocrine and exocrine cell lineages are affected in the mutant is compatible with the notion that these cell types arise from a common pool of Pdx-1-positive stem cells. Isl-1 is a LIM-homeodomain protein involved in insulin, somatostatin, and glucagon gene transcription in isl et cells (Karlsson 1990; Wang and Druckr 1995). It has two independent functions in the developing pancreas. Targeted disruption of the Isl-1 gene in the mouse abolishes the formation of an endocrine pancreas and inhibits the development of the dorsal pancreatic mesenchyme, an- 
other site of its expression (Ahlgren 1997). A loss of this latter tissue al ong the dorsal axis of the developing embryo in turn blocks development of the exocrine compartment in the dorsal but not the ventral bud. This provides genetic evidence for mesenchymal requirements during ontogeny of the exocrine tissue (Ahlgren 1997). M embers of the Pax gene family are also required for the specification of endocrine fate in the pancreas. Mice lacking Pax4 fail to devel op mature insulin- and somatostatin-producing cells (Sosa-Pineda 1997), while those lacking Pax6 are deficient for glucagon-producing cells (St-Onge 1997). Pax genes may be expected to act downstream of IsI-1 as inactivation of a single member of this gene family in the animal affects the formation of individual cell lineages rather than the whole endocrine compartment.

The factors that are specifically required for the early differentiation of the exocrine pancreas have been quite elusive. Exocrine pancreas-specific gene expression is under control of the cell-specific transcription factor PTF1, a hetero-oligomeric protein complex that binds to transcriptional enhancers of genes specifying the products of the exocrine pancreas (Cockell 1989). PTF1 is essential but not by itself sufficient for transcriptional activation of genes in this tissue since it needs to cooperatively interact with other transcription factors (C ockell 1995). The three distinct subunits of PTF1 are all members of the family of basic helix-loop-helix (bHLH) proteins (O. Hagenbüchle and P.K. Wellauer, unpubl.). p75 does not contact the DN A directly but is required for import of the factor into the cell nucleus (Sommer 1991). The two DNA-binding subunits, p64 and p48, recognize as a heterodimer a bipartite cognate site that contains two distinct sequence motifs. p64 contacts a TGGGA sequence whereas p48 binds to CAN NTG, the canonical binding site for bHLH proteins (Cockell et al. 1989; Roux et al. 1989). The p48 subunit, a B-class bHLH protein, is the only cell-specific constituent of the PTF1 complex (Krapp et al. 1996). It is the product of a single-copy gene (Knöfler et al. 1996). The p48 bHLH domain exhibits extensive sequence similarity with its counterparts present in other members of this protein family, in particular those that act as developmental regulators, such as the twist gene product, myogenic determinators, and factors involved in hematopoietic differentiation (for references, see Krapp et al . 1996). An antisense RN A-mediated reduction of p48 synthesis in exocrine pancreatic cells in culture inhibits the exocrine transcription program, showing that this protein is essential for maintaining the termi nal ly differentiated state (Krapp et al. 1996). Unlike myogenic factors, however, p48 on its own is not capable of establishing the general exocrine transcription program when constitutively expresse in a variety of different nonpancreatic cell lines in culture (A. Krapp, $O$. Hagenbüchle and P.K. Wellauer, unpubl.). In the developing mouse embryo, p48 synthesis precedes by several days the appearance of PTF1 at day 15 of gestation (Petrucco et al. 1990; Krapp et al. 1996). This observation suggested the possibility that p48 on its own played an alternative role during early embryogenesis.
In this report, we show that mice homozygous for a null mutation of the p48 allele lack the exocrine pancreas. The endocrine pancreas, while little affected by the mutation in the early embryo, dissociates and relocates to the spleen toward the end of embryonic development.

\section{Results}

Mice homozygous for a null mutation of the p48 allele lack the exocrine pancreas

The vector used for homologous recombination within the p48 locus in ES cells (HM-1) derived from the $129 \mathrm{~Sv} / \mathrm{J}$ mouse strain is shown in Figure 1A. Male mice displaying various degrees of the chimeric trait were mated with C57BL/ 6 females to generate independent mouse lines bearing the mutated p48 gene. Then, heterozygous offspring of these matings were bred for the production of animals homozygous for the mutation (Fig. 1B). Among a total of 178 newborn mice that were genotyped, only 16 animals (9\%) were found to be homozygous for the mutation. However, when pregnant females were sacrificed about 1 day before giving birth, the frequency of viable homozygous mutant embryos was close to that expected from Mendelian genetics (24 of 97), suggesting that the large majority of these animals survive embryonic development but die at birth. This conclusion is supported by observations made in instances when females giving birth could be di rectly surveyed. In all these cases, homozygous mutants were born live but invariably died within the $2-3 \mathrm{hr}$ period that precedes feeding. N ewborn -1 - animals are characterized by a bluish tint (suggesting some degree of cyanosis) and a slightly smaller body weight (Fig. 2a) and they are hypoglycemic, with blood glucose levels reduced by twothirds compared with their $+/$ - or $+/$ littermates (data not shown). Gross morphological examination discloses as the major phenotype the absence of pancreatic structures (Fig. 2b). Histology on whol e-mount sections of $-1-$ embryos at 18 days postcoitum (dpc) confirms the lack of recognizable pancreatic structures in the mesentery that normally harbors the pancreatic gland (Fig. 2c; and data not shown). Therefore, the reasons for the rapid postnatal death of $-1-$ mice are not clear as the observed morphological and biochemical defects (see below) are thought to permit survival for a considerably longer period of time. We do not exclude the possibility that the lethal condition results from an unrecognized efect in the nervous system where p48 is also expressed early during development (see Discussion).

The findings from morphological studies are substantiated by the comparative bi ochemical analysis of Figure 3. Total cellular protein and RN A of newborns and 16dpc embryos were extracted from tissue samples that included the stomach, the adhering spleen, and equivalent portions of the duodenum bearing or lacking the pancreas. Protein and/or RN A was then assayed for the presence of exocrine and endocrine pancreatic markers. The data from Western blot (Fig. 3a), N orthern blot (Fig. 

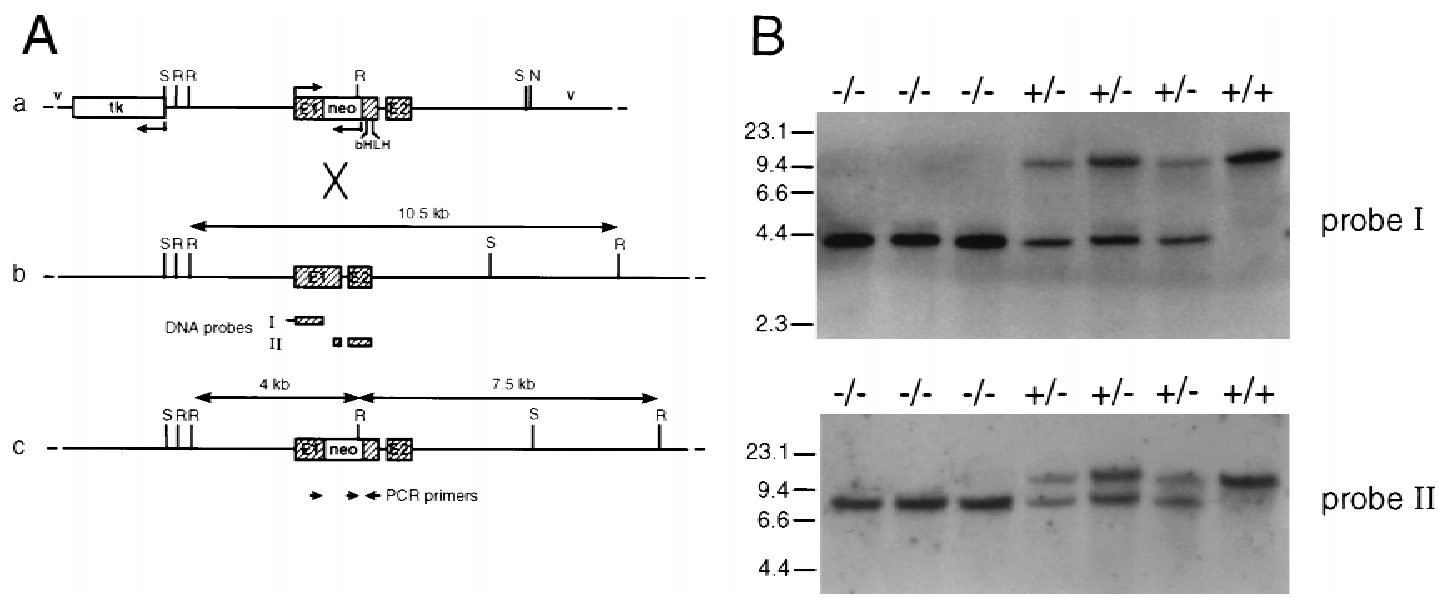

Figure 1. Targeted inactivation of the p48 gene by homologous recombination and genotype analysis of heterozygote interbreeding. (A) Schematic maps of the targeting vector (a), the wild-type p48 locus (b) and the mutated all ele (c). Exons are shown as hatched boxes and intronic or gene flanking sequences as heavy lines. Bacterial vector sequences $(v)$ are designated by thin lines. The direction of transcription is indicated by bent arrows. The herpesvirus tk gene and the neo gene used for negative and positive sel ection, respectively, are in the opposite transcriptional orientation to the p48 gene. The neo cassette was inserted into exon 1 (E1) of the p48 gene upstream of the bHLH sequence. Cleavage sites for restriction endonucleases Sacl (S) and N otl (N) were those used for construction and linearization of the targeting vector, respectively. Cleavage at EcoRI sites (R) was used to distinguish between wild-type and mutant alleles. The diagnostic EcoRI fragments are highlighted by double-headed arrows, and their size is shown. The origin of radiolabeled DN A probes used for filter hybridizations in B is indicated bel ow the map of $b$. The position and polarity of oligonucleotide primers used for PCR amplification are represented by the small arrows bel ow the map of C. (B) Southern analysis of EcoRI-digested genomic DN A of newborn littermates from a $+/$-interbreeding. DN A probes I and II both detect a 10.5-kb restriction fragment of the wild-type al lele. In addition, probe I detects a 4-kb fragment, and probe II a 7.5-kb fragment, of the mutant al lel e. Subsequent genotype analysis was carried out by PCR on tail DNA with the gene-specific primers shown in A (data not shown).

3b), and RT-PCR (Fig. 3c) analyses all show that the synthesis of exocrine markers in general, and p48 in particular, is impaired in -1 -animals. No significant differences are observed between $+/+$ and $H-$ animals with respect to the accumulation of $\alpha$-amylase mRN A or protein, suggesting that one functional p48 allele is sufficient to sustain wild-type level expression of the gene encoding this exocrine marker. The fact that p48 mRN A is lacking in the homozygous mutant, as deduced from the absence of a diagnostic 713-bp PCR product (Fig. 3c), proves that the genome of these animals bears a null allele. Polyclonal antibodies directed against exocrine pancreatic products, such as $\alpha$-amylase or carboxypeptidase $A$, failed to detect immunopositive cells in $-1-$ animals at all developmental stages examined, including 12 $\mathrm{dpc}$, the earliest stage at which exocrine differentiation markers could be reliably detected by immunohistochemistry (Fig. 4). The combined evidence from biochemical and cytological studies thus argues strongly in favor of the absence of an exocrine pancreas in the null mutant from $12 \mathrm{dpc}$ onward.

Cells expressing endocrine pancreatic functions persist throughout the entire life span of the p48-null mutant mouse

Products diagnostic for all endocrine islet cell types are detected in $-1-$ newborns, suggesting that at least part of the endocrine compartment persists until birth. However, the steady-state levels of both insul in and gl ucagon
mRN As are considerably lower in -1 -than in $+1+$ or $+1-$ mice (see Fig. 3b). This reduced number of insulin transcripts correlates with a lower level of protein in the blood of $-1-$ newborn mice $(4.2 \mu \mathrm{U} / \mathrm{ml})$ and $16-\mathrm{dpc}-1-$ embryos $(2.8(\mu / \mathrm{ml})$ as compared with their $+/$-counterparts $(13.7 \mu \mathrm{U} / \mathrm{ml}$ and $10.4 \mu \mathrm{U} / \mathrm{ml}$, respectively). This inefficient expression of endocrine markers, which is diagnostic of a diabetic condition, may be explained by a lower synthesis and/or a more rapid turnover of these molecules inside the producing cells or by a smaller number of such cells and for insulin, in addition, by a less efficient secretion into the blood stream.

To verify whether the absence of exocrine and the presence of endocrine pancreatic cells in the $-l-$ mice as inferred from biochemical analysis was also true at the cellular level, we have carried out a comprehensive immunocytochemical study on wholemount serial secti ons derived from 12-, 16-, and 18-dpc embryos. A series of polyclonal antibodies directed against insulin (or C peptide), glucagon, somatostatin, and pancreatic polypeptide were used to distinguish among endocrine $\beta, \alpha$, $\delta$, and $\gamma$ cell types, respectively. The specificity of these antibodies was tested in immune reactions with both adult and 18-dpc pancreas of $H+$ and $H-$ mice but is shown here only for the embryo (Fig. 5). The immunostaining reactions yield the characteristic distribution of the various endocrine cells inside the Langerhans isl ets, with insulin- and $C$ peptide-producing $\beta$ cells forming the core (Fig. 5a,b,e) and $\alpha, \delta$, or $\gamma$ cells being located at the periphery (e.g., Fig. 5f,g). The double-staining reac- 


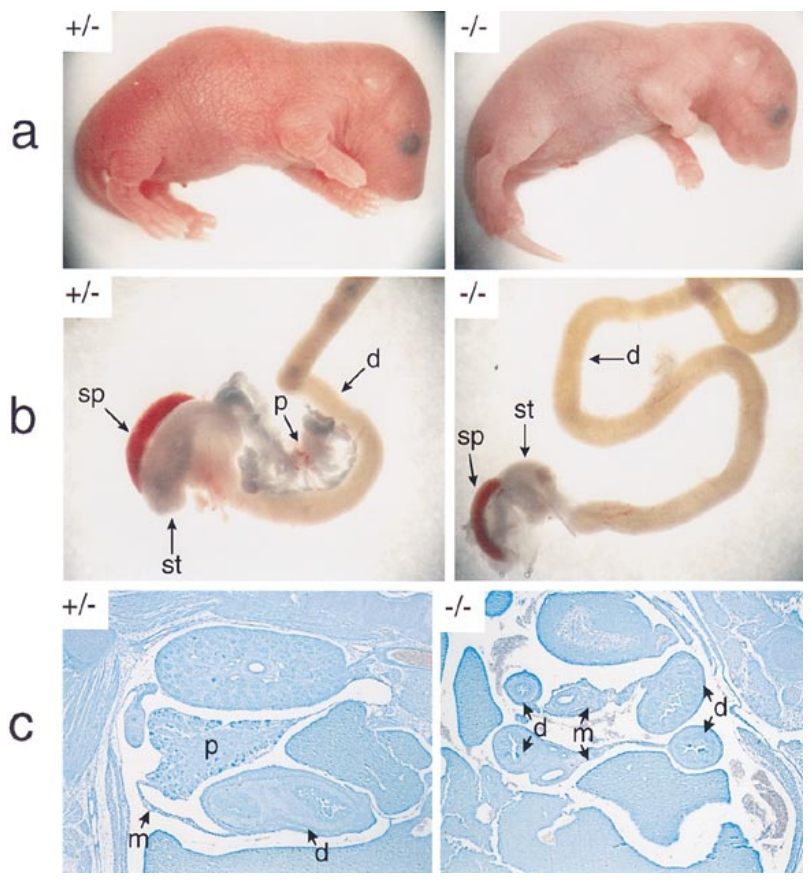

Figure 2. The p48-deficient mouse lacks recognizable pancreatic structures. The $+/-$ and $-1-$ newborn mice shown in a are from the same litter of a $\mathrm{H}-$-interbreeding. Both animals were alive when their pictures were taken ( $1 \mathrm{hr}$ after birth). $\mathrm{N}$ ote the slender body shape and the smooth texture and bluish color of the skin in the null mutant. The dissected intestinal tracts of these animal s are compared in b. Only the rel evant region of the intestine that harbors the pancreatic gland in wild-type mice is shown. In c, the abdominal region was examined in wholemount sagittal sections of 18-dpc $+1-$ and $-1-$ embryos after staining with Giemsa. $d$, duodenum; $m$, mesentery; $p$, pancreas; sp, spleen; st, stomach. Abbreviations used are the same for Figs. 4-7. Photographs of $+/$-and -1 -genotypes in $a, b$, and c are shown at the same relative magnification.

tion of Fig. 5h shows that the nucleus of insulin-producing cells al so stains positively for the homeobox protein $\mathrm{Pdx}-1$, as expected. In 12- and 16-dpc -1 -embryos, cells positive for endocrine markers are detected inside mesenterial structures, where they appear to be localized mostly at the periphery of, or intermingled with, the epithelial lining of ductlike structures (Fig. 6). The number of glucagon-positive cells appears initially (12 dpc) little affected by the p48 mutation (Fig. 6, cf. a and b; and data not shown). At $16 \mathrm{dpc}$, however, these and other endocrine cells are more scarce in -1 -as compared with $H-$ embryos, suggesting that their proliferation and/or maturation is negatively affected by the mutation (Fig. 6 , cf. gand h; data not shown). The low levels of insul in and glucagon mRNA (or insulin in the blood) of 16-dpc -1mice (see Fig. 3) thus correlates with a reduced number of endocrine cells at this particular stage of devel opment.

The endocrine compartment disassembles, and cells expressing its markers appear in the spleen toward the end of embryonic life

To our surprise, no cells expressing any of the above endocrine markers were detected in the neighborhood of intramesenterial ducts in $-1-$ newborns or 18-dpc embryos (as exemplified by the absence of insulin staining in Fig. 7a). This finding was unexpected as it apparently contradicted the data obtained by biochemical analysis that clearly showed that not only embryonic but also newborn $-1-$ mice expressed, although inefficiently, both insulin mRN A and its product (see Fig. $3 \mathrm{~b}$ and the text). A survey of an entire 18-dpc $-1-$ embryo led eventually to the discovery of cells expressing endocrine pancreatic functions in the spleen, a mesoderm-derived tissue (Fig. 7b-f). Subsequent analysis disclosed such cells also to be present in the spleens of newborn -1 -animals (Fig. 7g). They were not observed, however, in spleens of $H-$ mice or $-1-$ embryos at $16 \mathrm{dpc}$ (see representative examples in Fig. 7h and i, respectively). Their presence in the spleen of newborn $-1-$ mice provides a reasonable explanation for the results from biochemical studies as RNA was originally extracted from samples that included this tissue (see Fig. 3 b,c and the text). Immunocytochemistry proved positive for the detection of insulin, glucagon, somatostatin, and pancreatic polypeptide (ppp), suggesting that foreign cells expressing these markers in the spleen originate from all four endocrine pancreatic lineages. Such an assignment is strengthened by the observation that, for example, insulin and Pdx-1 are coexpressed in such cells, which is compatible with an origin from the endoderm (Fig. 7g, inset). Cells expressing endocrine pancreatic markers are scattered individually throughout the spleen and do not assemble into any particular higher order morphological structures during the short life span of the animals. They are apparently not apoptotic as their nuclear DNA does not contain the single-stranded breaks commonly associated with the onset of cell death (Fig. 8). The experimental evidence supports amodel by which the endocrine compartment initial ly present in the null mutant relocates to the spleen between 16 and $18 \mathrm{dpc}$, where its cells persist in a functional state until neonatal death. Therefore, it is possible that these cells are competent of long-term survival at their ectopic site.

\section{Discussion}

We have shown that targeted inactivation of the gene for the exocrine pancreas-specific p48 subunit of transcription factor PTF1 in the mouse yields an early postnatal lethal phenotype characterized by a lack of the exocrine pancreas. p48 is so far the only factor known to be specifically required for the ontogeny of the exocrine pancreas. We show that exocrine cells are absent from 12 dpc onward indicating that p48 is essential for their differentiation and/or proliferation. The fate of exocrine cells prior to this stage is not known. It is possible that they form normally in the mutant but enter an apoptotic pathway early on. This question cannot be addressed at the present time as we lack appropriate histological markers to identify exocrine cells in the p48 $-1-$ mouse prior to $12 \mathrm{dpc}$. One approach that might circumvent this problem would be to study the formation of pancre- 
Figure 3. The p48-null mutant is deficient for exocrine pancreatic functions. (a) Western bl ot analysis for the immunodetection of pancreatic $\alpha$-amylase in extracts containing total protein derived from dissected gastrointestinal tracts and the adhering spleens of newborn $H+, H-$, or $-1-$ littermates. The prominent band at $56 \mathrm{kD}$ in $+/+$ and $+/-$ samples is $\alpha$-amylase. (b) Northern blot analysis for the detection of exocrine and endocrine mRN As. Total RN A of newborn (nb) and 16-dpc embryos was isolated from samples containing the tissues described in a. The relative accumulation of pancreatic mRNAs at steady state was estimated by comparison to the signal produced by the mRN A for intestinal fatty acid binding protein (Fab). (c) RT-PCR for the detection of mRNAs diagnostic for the exocrine and the four different endocrine cell lineages in two newborn $+1-$ and -1 - littermates each. Ethidium bromide-stained PCR products are shown in reverse contrast. Their size was estimated by comparison to a commercial 100-bp DNA ladder. The numbers on the right of the gel pictures show the actual size in base pairs as deduced from the DNA sequence. The specificity of each amplification reaction was monitored by including a no cDN A control (Co). Weak bands for carboxypeptidase A and elastase 1 were often seen in amplification reactions of $-1-$ samples. Their presence suggests that cells expressing low levels of transcripts for these exocrine markers persist in the gastrointesinal tract even though we have never detected their protein products by immunohistochemistry.

atic buds in a knock-in mutant containing an allele that expresses a cytological marker, such as lacZ or GFP, under control of the p48 gene promoter.

The evidence accumulated from a large number of studies is compatible with a model that views the development of the mammalian pancreas as a process governed by a hierarchy of different transcription factors that exert their function in a sequential temporal order (Fig. 9). Pdx-1 is critical for the specification of the early pancreatic parenchyma as it permits cell proliferation and the initial branching into endocrine and exocrine cell lineages to occur. Then, subsequent differentiation of the endocrine and exocrine compartments requires the action of homeobox protein Isl-1 and bHLH protein p48, respectively. The onset of exocrine transcription in the devel oping mouse pancreas occurs between 10.5 and $12 \mathrm{dpc}$ (Gittes and Rutter 1992), that is, several days prior to the stage $(15 \mathrm{dpc})$ when extensive proliferation and cytodifferentiation cumulate in the appearance of zymogen granules in the cytopl asm (Wessel Is and Cohen 1967) and a drastically enhanced exocrine transcription rate caused by PTF1 binding activity in the nucleus (Petrucco et al. 1990). Pdx-1 has been observed in pancreatic progenitor cells as early as $9 \mathrm{dpc}$ (Guz et al . 1995; A hlgren et al. 1996; Offield et al. 1996). We have detected p48 transcripts as early as $12 \mathrm{dpc}$ by standard PCR methods and, more recently, at $9 \mathrm{dpc}$ by cloning of PCR-amplified mRN A 5' ends (O. Hagenbüchle, unpubl.). The cellular origin of these early transcripts is still unknown, how- ever, as p48 mRNA synthesis al so occurs in the neural tube around this time of development (M. Kawaichi and $\mathrm{H}$. Edl und, pers. comm.). In situ hybridization has shown that p48 mRN A is restricted to the acinar compartment from $14 \mathrm{dpc}$ onward (Krapp et al. 1996). However, attempts to determine the onset of p48 gene expression by cytological methods so far have not been successful. This has precluded visualization of exocrine pancreatic progenitor cells which, we predict, should coexpress Pdx-1 and p48. Interestingly, the genes encoding these factors contain, in their upstream control regons, a sequence el ement which, in vitro, is a high-affinity binding site for the product of the other gene, suggesting reciprocal transcriptional regulation $(\mathrm{O}$. Hagenbüchle and P.K. Wellauer, unpubl.). It would thus be useful to determine whether p48 synthesis occurs in the pancreas anlage of Pdx-1-deficient mice. Furthermore, the epistatic relationship of p48 and factors present in the notochord and/or the pancreatic mesenchyme needs to be elucidated. N otochord signal ing has been shown to be essential during the initial specification of endoderm to dorsal pancreas in the chick (Kim et al. 1997) as it represses the expression of Sonic hedgehog, an intercel lular patterning signal that is specifically absent from pancreatic endoderm (A pelqvist et al. 1997; Hebrok et al. 1998). M esenchyme signaling is required for the subsequent proliferation and cytodifferentiation of the exocrine compartment (Wessells and Cohen 1967; Spooner et al. 1970; Gittes et al. 1996; Ahlgren et al. 1997). 


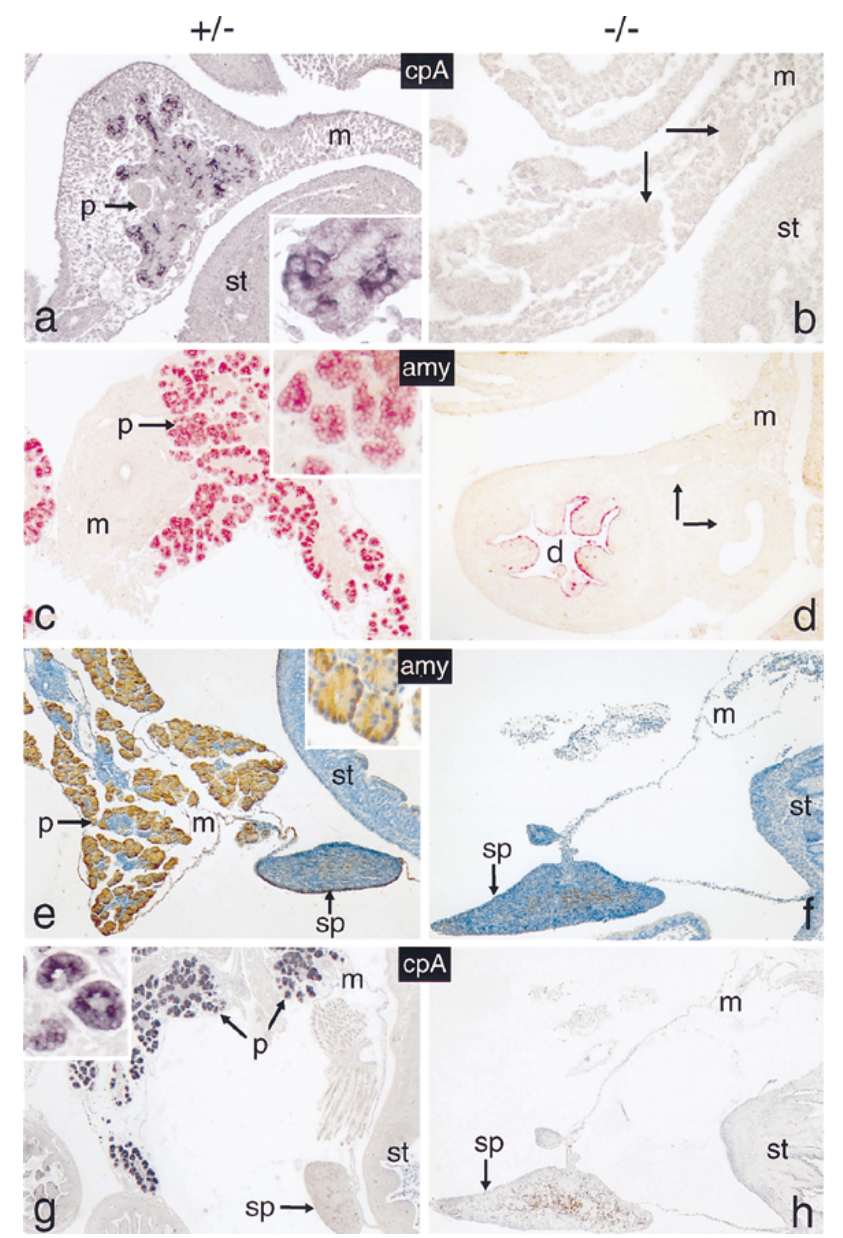

Figure 4. The p48-null mutant lacks cells expressing exocrine functions. Sagittal tissue sections of whole-mount 12 -dpc $(a, b)$, 16-dpc (c,d) and 18-dpc (e-h) $+1-$ or -1 -embryos were analyzed for the presence of cells producing carboxypeptidase A (cpA; blue color) or $\alpha$-amylase (amy; red or brown color). Arrows in $b$ and d designate cell masses that stain positive for endocrine markers in butterfly sections shown in Fig. 6, b and e, f, and h), respectively. Cell nuclei in e and $f$ were counterstained with hematoxylin. The insets of a, $c$ and e emphasize the cytoplasmic location of the markers. All panels are shown at the same relative magnification. Tissue in this and all subsequent figures is oriented such that caudal is toward the top, distal toward the bottom, ventral toward the left and dorsal toward the right.

We have made the intriguing observation that cells of the endocrine compartment disappear from their original location, and that cells expressing endocrine functions reappear in the spleen late during development (16-18 $\mathrm{dpc}$ ) of the null mutant embryo, where they remain in a functional state until neonatal death of the organism. What is the nature of these endocrine cells in the spl een? We have no formal proof to show that they originate from segregation of the endocrine compartment rather than by a de novo transdifferentiation event in the spleen. Transdifferentiation of spleen into endocrine pancreatic cells is an unlikely explanation for the observed phenomenon, however, as there is no precedence showing that this process can occur across germ layer boundaries. The cells expressing endocrine pancreatic functions in the spleen must derive from the endoderm as we have shown for the insulin-producing cells that they coexpress Pdx-1, which is not synthesized in the mesoderm from which the spleen origi nates. Therefore, we may reasonably assume that the presence of insulin, and presumably also glucagon-, somatostatin-, and pppproducing cells in this tissue is the result of an invasive process. Several different pathways may be envisaged by which this immigration occurs, such as transport through the blood stream (which is improbable as cells would have to pass across blood vessel walls), lymphatic drainage, or migration through the mesentery. There is

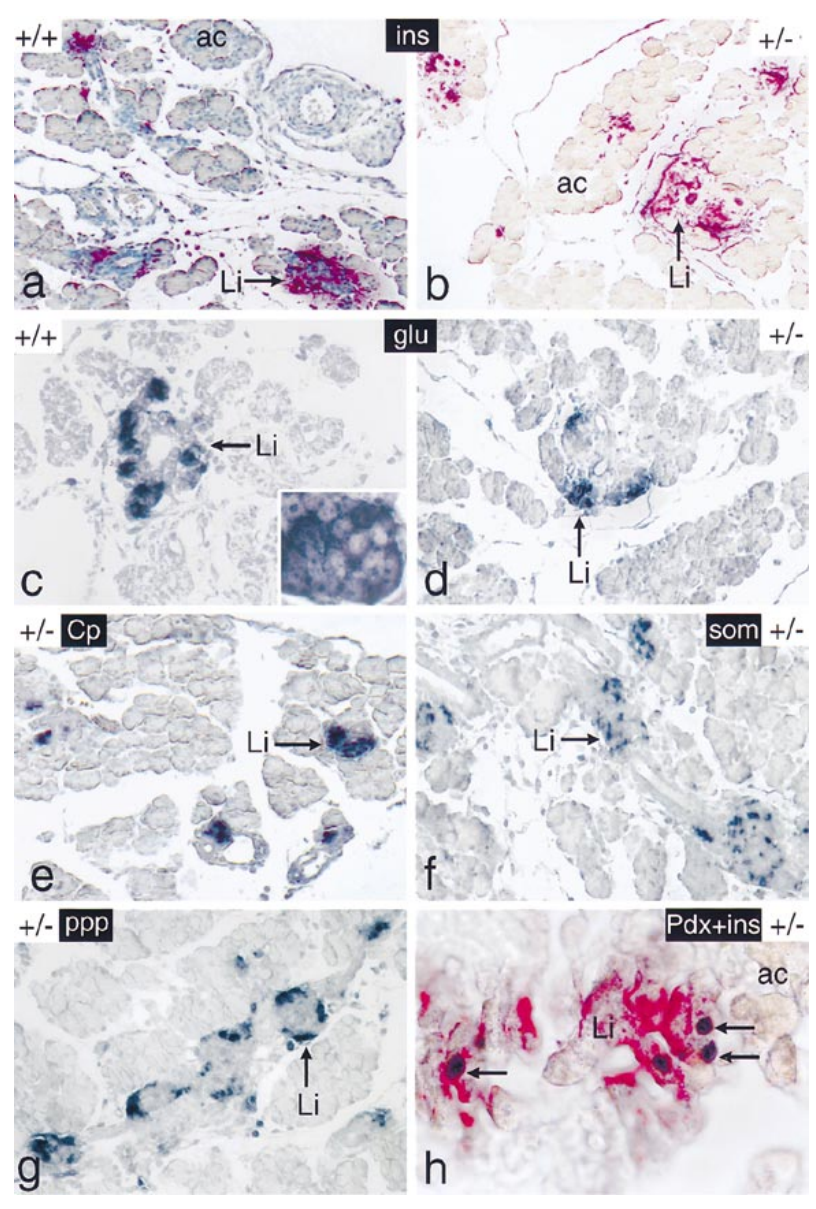

Figure 5. The endocrine pancreas of newborn mice bearing one inactive p48 allele shows a normal structural and functional organization. Tissue sections of dissected intestinal tracts derived from 18-dpc $+/+$ and $+/-$ mice were analyzed for the expression of markers diagnostic for the endocrine ( $\mathrm{Li}$ ) compartment of the pancreas, such as insulin (ins; red color), glucagon (glu; dark blue color), C peptide (Cp; dark blue color), somatostatin (som; dark blue color), and pancreatic polypeptide (ppp; dark blue color). The pancreas in $\mathrm{h}$ was assayed for the simultaneous presence of insulin (red color) and Pdx-1 (dark blue color) in the $\beta$ cell cytoplasm and nucleus (arrows), respectively. The pancreas of a was counterstained with hematoxylin. The inset of c highlights the cytoplasmic localization of the immunostain. Panels a-g are shown at the same relative magnification. 


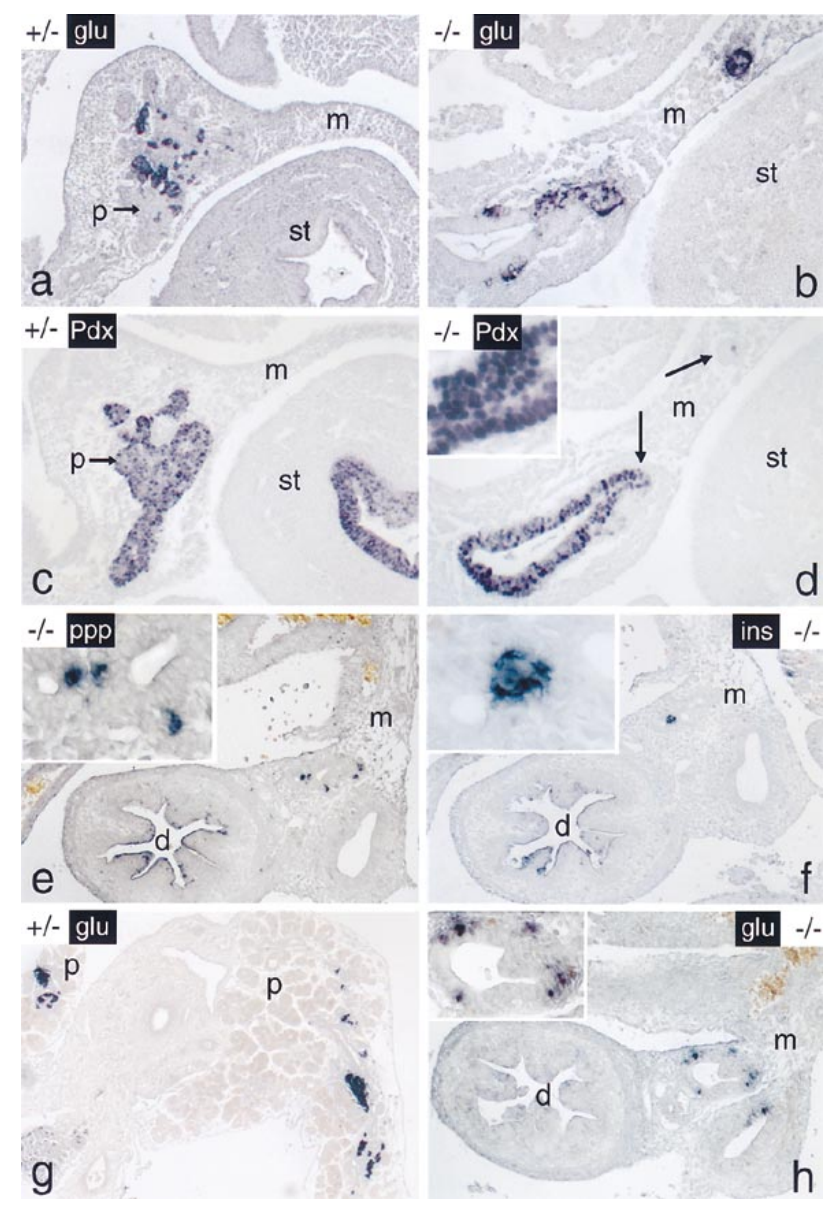

Figure 6. Cells expressing endocrine functions persist in the p48-null mutant embryo. The endocrine markers indicated (see Fig. 5 for abbreviations) were localized in whole-mount sections from 12-dpc a-d and 16-dpc e- $\mathrm{h}+/-$ and $-1-$ embryos by immunostaining. N ote that endocrine cells of $-1-$ mice are closely associated with intramesenterial ductlike structures at both developmental stages. Arrows in d designate cellular aggregates that stain positive for glucagon in the adjacent serial section of b. Panels for a given devel opmental stage are shown at the same final magnification. (Insets) Detail at a higher magnification.

some evidence to suggest that this latter mechanism applies as individual cells expressing endocrine pancreatic functions are routinely routinely inside the mesentery adjacent to the spleen around the developmental period when they appear in this tissue (e.g., see Fig. 7e). If this ability to colonize the spleen in the absence of an exocrine acinar compartment is indeed an inherent property of endocrine pancreatic cells, it suggests that these cells lack (or have lost) positional memory. Two alternative explanations may account for the observed phenomenon. One of these assumes that the endocrine cells originate from the ductual epithelium that fails to grow and branch in the p48 -1 -mouse. This event would alIow endocrine cells to migrate freely into the adjacent mesenchyme (the presumptive mesentery) and eventually into the spleen as they would not be trapped physically by the developing ductal and exocrine epithelium.
The dorsal pancreatic mesenchyme and the spleen both develop from condensation of the dorsal mesogastrium (A pelqvist et al. 1997). This common origin may provide a plausible explanation for the observation that endocrine cells can move freely through the surrounding mesoderm in the p48 $-1-$ mouse. The fact that migration starts only once the spleen has formed (this organ develops around $13 \mathrm{dpc}$ ) suggests that additional parameters are required for this process to occur relatively late during devel opment. In this context, it is interesting to note that the time period between 16 to $18 \mathrm{dpc}$ coincides with the activation of a matrix metalloprotease (M MP2; Birkedahl-Hansen 1995) that is concentrated at sites of tissue remodeling and apparently all ows endocrine cells to move from the ductal epithelium into the developing exocrine compartment during normal organogenesis ( $R$. Scharfmann, pers. comm.). Another possibility is that the correct stereospecific assembly of the pancreatic gland is not merely the result of a physical trapping of endocrine by exocrine cells but requires cross-talk between these two cell types. There is some evidence for such a hypothesis as mice deficient for the gene encoding Beta2 (N euroD), a bHLH protein expressed in the endocrine pancreas and the brain ( $\mathrm{N}$ aya et al. 1995), not only fail to develop mature islets but also exhibit acinar cell defects, notably a loss of the polarized intracellular organization and an abnormal abundance of zymogen granules leading to a structural degeneracy of these cells after birth ( $\mathrm{N}$ aya et al. 1997). It has been suggested that these cellular abnormal ities are caused by the absence of CKK and seretin, which are both required for secretion of the exocrine products, as cells producing these peptides are lacking in the small intestine of the null mutant ( $\mathrm{N}$ aya et al. 1997). It has not been excluded, however, that the morphological changes occurring within the exocrine cells of Beta2-deficient mice are, at least in part, due to the lack of mature endocrine islets. If a physical and possibly also a functional interaction between the two cellular compartments is indeed important for normal morphogenesis of the pancreatic gland, it is likely to involve cell adhesion molecules. The aberrant spatial organization and the retarded maturation of cells from the endocrine compartment in the p48 $-t-$ mouse could be due to the absence of a particular combination of cell adhesion molecules normally provided by the exocrine cell but lacking in other cell types present inside the mesentery. These cell-surface glycoproteins, which include cadherins, catenins, and integrins, are thought to play an important regulatory role during tissue morphogenesis by establishing cell-cell contacts through homoand heterotypic interactions (Volk et al. 1987; N ose et al. 1990). M embers of the cadherin protein family are suspected to be involved in cell sorting and differentiation (N ose et al. 1988). During pancreas ontogeny, they are differentially expressed in islet and exocrine cells and appear to be critical players during the aggregation of endocrine cell types (Moller et al. 1992; Hutton et al. 1993; Cirulli et al. 1994; Sjödin et al. 1995; Dahl et al. 1996). In view of such a hypothesis, it would be useful to establish the repertoire of cell adhesion molecules in the 

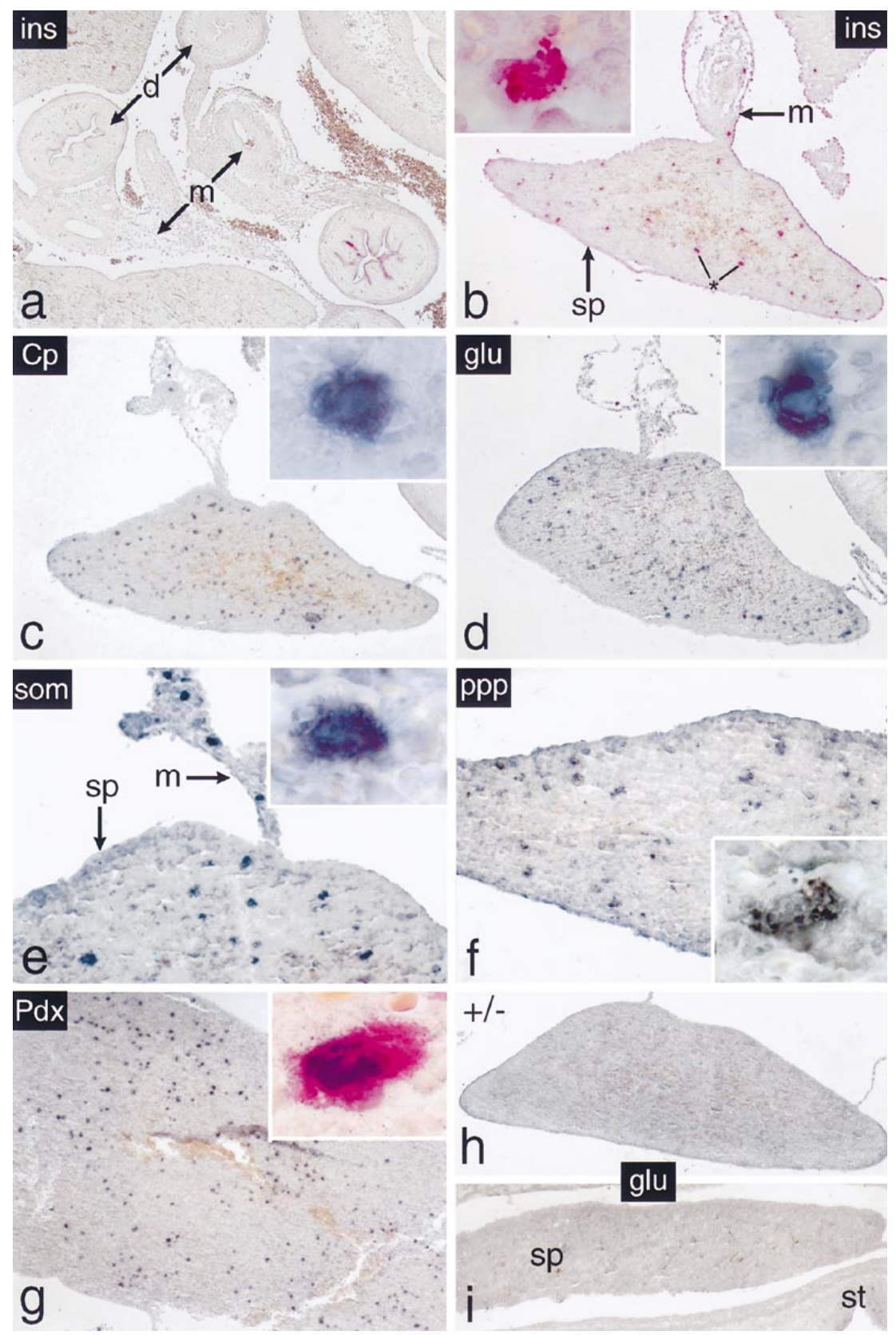

Figure 7. Cells expressing endocrine functions appear in the spleen of p48-deficient mice. Immunohistochemistry was carried out on dissected intestinal tracts of 18-dpc -1 -embryos (b-f) or from spleen of newborn $-1-$ mice (g). (a) The abdominal region of an 18-dpc -1 -embryo showing, in this particuIar case, that insulin-producing cells are absent from the intestinal mesentery. Individual cells expressing the endocrine markers indicated were detected exclusively in spleens of $-t-$ mice from $18 \mathrm{dpc}$ onward. They were not observed in spleens of $+H-$ mice (h) or 16-dpc -1 -embryos (i) as exemplified by the absence of glucagon staining. (Insets) Single intrasplenic cells positive for the respective endocrine markers at a higher magnification. (Inset in g) Cell simultaneously expressing insulin in its cytoplasm (red color) and Pdx-1 in the nucleus (dark blue stain). Note that individual immunopositive cells are also present in the mesentery adjacent to the spleen (e.g., in e). exocrine pancreatic cell and the spleen and to elucidate their interplay with the endocrine counterparts.

The reason why cells expressing endocrine functions settle exclusively in the spleen is not obvious at this time. One would also expect the gut mucosa or the liver, both of which derive from endoderm, to be appropriate sites for repopulation by endocrine pancreatic cells. The intestine in particular would appear a logical choice as it harbors some dispersed glucagon, somatostatin-, and ppp-expressing cells in all vertebrates as a remnant from ancient times when such cells were present exclusively in the mucosa of the digestive tract (for review, see Falkmer 1985). One explanation may be that access to these organs is denied for some reason, whereas the spleen proves a suitable alternative as it is permissive for the mechanism by which transl ocation occurs. There is evidence to show that the spleen supports sustained growth of endodermal cells as hepatocytes have been observed to repopulate not only the liver and the pancreas but also the spleen upon injection into mice or rats (see Gupta et al. 1992 and references cited therein). When transplanted into the splenic pulp, hepatocytes aggregate, proliferate, and survive in a functional state for an extended period of time. Colonization of the spleen by endocrine pancreatic cells may not merely be a fortuitous event but may constitute a default pathway conserved during evolution. In some reptiles, giant islets devoid of exocrine parenchyma occur in the spleen, where they form a structure that is homologous to the Brockmann bodies, the principal islets in some species of bony fish (for review, 


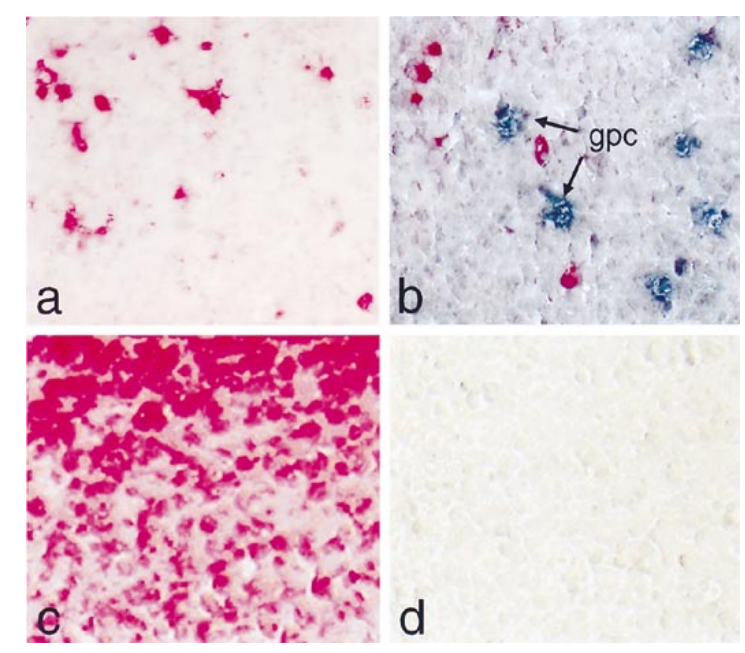

Figure 8. Intrasplenic cells expressing glucagon are not apoptotic. (a) A poptotic nuclei in the spleen (red col or) are visual ized by chromogenic detection of anti-DIG antibody without treatment with DN ase I. (b) Same as a but using, in addition, an antibody for the simultaneous detection of glucagon producing cells (gpc; blue color). (c) Same as a but including a DN ase I digestion step prior to the incorporation of label ed nucleotide as a positive control. (d) Same as a but omitting terminal transferase as a negative control.

see Falkmer 1985). Although intrasplenic islets are not known to exist in mammals, we may envision that endocrine cells are still imprinted by this ancient evolutionary trait that is evidenced only when the morphogenetic process leading to the appropriate three-dimensional organization of the gland is disabled such as is the case in the p48 - - mouse.

\section{Materials and methods}

\section{Targeted inactivation of the PTF1-p48 gene}

The targeting vector for positive/negative selection was constructed as follows. A $8.5-\mathrm{kb}$ Sacl fragment of $129 \mathrm{~Sv}$ J mouse DN A harboring the entire p48 gene plus flanking sequences, in which the unique Notl site of the first exon was deleted, was cloned into the Sacl site of a pGEM 3 vector (Promega) bearing a modified multiple cloning sequence (MCS) (Clal-Sacl-N otl). A 1.1-kb Sall-Xhol fragment containing the neomycin-resistance gene (neo) of pMClneoPolyA (Stratagene) was blunt-ended, ligated to a Smal-Mlul adaptor having an in-frame translation stop codon, and inserted into the unique Mlul site in exon 1 of the gene upstream of the DN A that specifies the bHLH domain. The recombinant plasmid was then cleaved at the unique Clal site of the MCS, blunt-ended, and ligated to a $2.7-\mathrm{kb}$, bluntended HindIII-EcoRI fragment carrying the herpesvirus thymidine kinase (tk) gene linked to the PGK-1 promoter and poly(A) site.

The DNA of this 15.3-kb targeting vector was linearized at the $\mathrm{N}$ otl site of the M CS for stable integration into the genome of HM-1 ES cells from the 1290la mouse strain (Magin et al. 1992; a gift of D.W. M elton, Harvard U niv., Boston, M A). A bout $10^{7}$ cells were el ectroporated in $0.8 \mathrm{ml}$ of serum-free medium with the DNA $(20 \mu \mathrm{g} / \mathrm{ml})$ at $500 \mu \mathrm{F}$ and $280 \mathrm{~V}$ using a Gene
Pulser (Bio-Rad). The cells were seeded into 90-mm gel atinized petri dishes in DMEM medium containing $10^{3} \mathrm{U} / \mathrm{ml}$ of recombinant leukemia inhibitory factor (ESGRO; Gibco-BRL). Selection was started $24 \mathrm{hr}$ later in the above medium, first for 2 days with $350 \mu \mathrm{g} / \mathrm{ml} \mathrm{G} 418$ (Gibco-BRL) alone and then with $2 \mu \mathrm{m}$ Gancyclovir (Roche Bioscience, Palo Alto, CA) in addition. Ten days after the beginning of selection, colonies were picked and expanded into cell lines. For the detection of homologous recombination events at the p48 locus, DNA was isolated from the various cell lines as described by Laird et al. (1991), digested with EcoR I and analyzed on Southern blots with a radiolabeled 2.9-kb Sacl-EcoRI fragment of the distant 3' flanking region of the gene as a probe. This probe detects 10.5- and 7.5-kb EcoRI fragments of the wild-type and mutant alleles, respectively. Then, the cells of clones in which homologous recombination had occurred were used to generate mouse chimeras as described by Bradley (1987). Aliquots of 10-15 cells were injected into the blastocoele cavity of C57BL/ 6 blastocysts at $3.5 \mathrm{dpc}$. Blastocysts were transferred to the uterus of pseudopregnant $\mathrm{N} \mathrm{MRI}$ foster mothers 2.5 days after mating with sterile N M RI males. Male chimeric progeny exhibiting various degrees of the chinchilla coat color were then mated to C57BL/ 6 females to obtain heterozygous mice. Tail DN A from the offspring of these matings was analyzed as above on Southern blots for germ line transmission of the mutated al lele. Subsequent genotype analysis was carried out by PCR with the following combination of

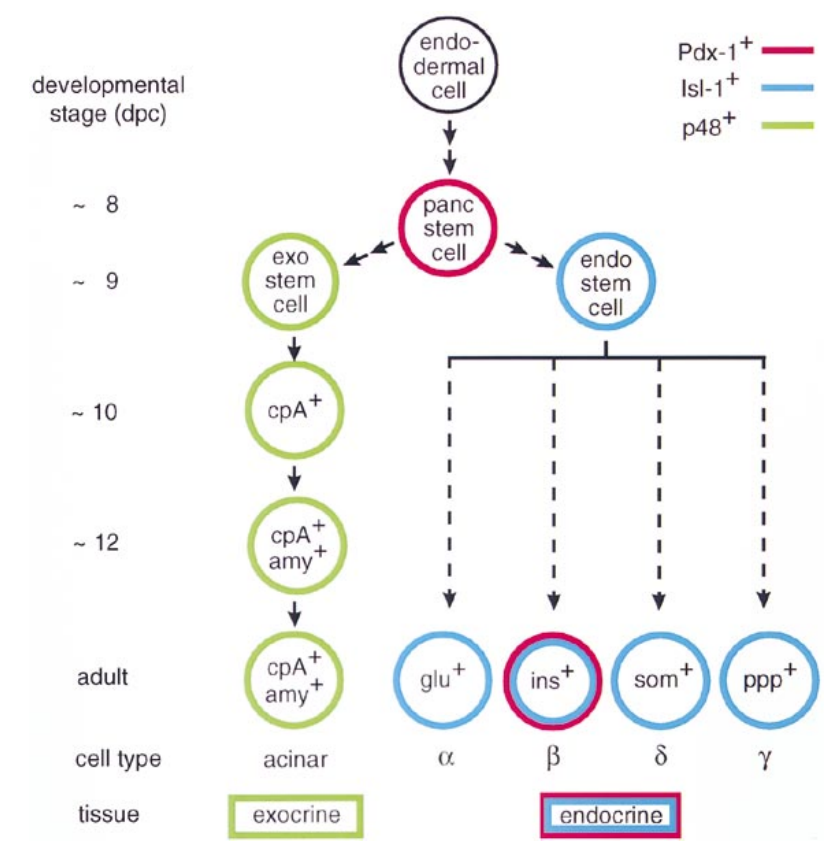

Figure 9. The origin of the exocrine and the endocrine cell lineages in the mammalian pancreas. The model for the exocrine cell lineage is based on results described in this paper but al so incorporates data from other laboratories (Gittes and Rutter 1992; Guz 1995). The origin of the various endocrine cell lineages is shown for completeness and is based on data from the literature (e.g., see Larsson 1996). Arrows in the diagram are not meant to imply a precursor-product relationship between the different cells of a given lineage but rather suggest a sequential order of events deduced from the localization of cell-type-specific markers in the developing pancreas of wild-type and mutant mice. The early target genes of bHLH protein p48 and homeodomain proteins Pdx-1 or Isl-1 are not known. 
gene-specific primers: p48 plus-strand (+) primer, 5'-GTACTCCTGGAGCACTTCC-3'; p48 minus-strand (-) primer, 5'-GGCGTCGTTGATGGACTGC-3'; and neo (+) primer, 5'-ATTGCATCAGCCATGATGGA-3'. DNA amplification with these primers was carried out at $55^{\circ} \mathrm{C}$ for 30 cycles.

\section{Histology}

M ouse embryos were removed from the uterus in sterile PBS, staged as described previously by Petrucco et al. (1990) and cut in half sagittally with a razor blade. Embryo halves were transferred to $10 \%$ formaline stabilized with the same buffer and fixed overnight at $4^{\circ} \mathrm{C}$. Tissue was processed in the same manner, except that fixation was for $3 \mathrm{hr}$ only. Then, the biological material was dehydrated through a graded ethanol series into xylene according to standard procedures and embedded into paraffin in a vacuum oven set at $60^{\circ} \mathrm{C}$. Serial sections $(4-6 \mu \mathrm{m})$ of paraffin-embedded whole-mount embryos or tissue samples were made by use of a microtome and transferred to microscopic slides coated with silane (Sigma). Tissue sections were dewaxed and rehydrated as described previously (Krapp et al. 1996).

\section{Immunohistochemistry}

Rabbit primary antibodies directed against pancreatic $\alpha$-amyIase (Calbiochem), carboxypeptidase A (Anawa, Wangen, Switzerland), insulin (Novocastra, N ewcastle upon Tyne, UK), C peptide (gift of $\mathrm{O}$. Madsen, Hagedorn Research Institute, Gentofte, Denmark), glucagon (Anawa), somatostatin (ICN Biomedicals), ppp (Chemicon), and Pdx-1 (gift of H. Edlund, Umea University, Switzerland) were all used at 1:1000 dilutions. The specificity of the various antisera was tested on newborn and adult wild-type pancreas sections that were processed in parallel with tissue derived from mice homo- or heterozygous for the PTF1-p48 mutation. Slides containing tissue sections were heated in PBS for $5 \mathrm{~min}$ at $90^{\circ} \mathrm{C}$ on a hot plate before the immune reactions were carried out. Incubations with primary antibodies were performed in a seal ed box for $2 \mathrm{hr}$ at $37^{\circ} \mathrm{C}$. Primary anti bodies were detected with a commercial biotin-streptavidin system (Amersham). The bi otinylated anti-rabbit secondary antibody and the streptavidin-peroxidase or streptavidin-alkal ine phosphatase conjugates for chromogenic detection were used as specified by the supplier. Peroxidase activity was visualized by the brownish color produced by applying DAB reagent (Sigma) for 5-15 min. In some instances, tissue sections were counterstained afterwards with hematoxylin. Alkal ine phosphatase activity was detected in 10-30 min incubations with either Fast Red (red color; Sigma) or N BT/BCIP (dark blue color; Sigma) substrates. Dual-color immunohistochemistry for the detection of two different antigens in the same tissue section was carried out sequentially. Once the chromogenic reaction for the first antigen was completed, slides were washed for 10 min with 0.1 M glycine- $\mathrm{HCl}(\mathrm{pH} 2.2), 0.1 \%$ T ween, three times for $5 \mathrm{~min}$ each with PBS, and then for 30 min with blocking agent before primary antibody for detection of the second antigen was applied. Tissue sections were embedded in Gurr's Aquamount (BDH, Poole, UK). Color photography was performed with a Zeiss photomicroscope fitted with a high resolution digital camera (Kontron Progress). Photographs throughout this report show the natural olors as produced by various chromogenic substrates. All conclusions made from immunohistochemistry data were based on the analysis of at least three individual mice for each developmental stage shown.

\section{TUNEL assay}

Nuclear DNA fragmentation in the spleen was visualized essentially as described by Gavrieli et al. (1992) with the following modifications. Enzymatic reactions were carried on paraffinembedded tissue rather than frozen material. Tissue sections were digested for $15 \mathrm{~min}$ at $25^{\circ} \mathrm{C}$ with $0.5 \mu \mathrm{g} / \mathrm{ml}$ proteinase $\mathrm{K}$ in $50 \mathrm{~mm}$ Tris- $\mathrm{HCl}$ (pH 7.5), $1 \mathrm{~mm}$ EDTA. In some experiments, protease treatment was followed by a 10 -min digestion at $25^{\circ} \mathrm{C}$ with $0.1 \mu \mathrm{g} / \mathrm{ml}$ DNase I in $30 \mathrm{~mm}$ Tris- $\mathrm{HCl}(\mathrm{pH} 7.5), 4 \mathrm{~mm}$ $\mathrm{MgCl}_{2}, 0.1 \mathrm{mM}$ DTT. Endlabeling at nicks in DNA with was performed with digoxigenin (DIG)-labeled dUTP (Amersham) and terminal deoxynucleotidyl transferase (Pharmacia). Incorporated nucleotide was visual ized by immunohistochemistry as described above by use of an anti-DIG-alkaline phosphatase conjugated antibody (Boehringer) and Fast Red as a chromogen.

\section{Determination of blood glucose and insulin}

Glucose was determined in peripheral blood of embryos and newborn mice by use of a commercial UV method (Boehringer) under the supplier's conditions. Insulin was determined in reactions containing $50 \mu \mathrm{l}$ of blood serum with the radioimmune assay (RIA) kit from Linco. Rat insulin was used as a standard. The numbers given in the text represent average values determined from measurements of three or more independent samples each containing blood pooled from several animals of the same genotype.

\section{RT-PCR}

Whole-cell RNA was isolated from dissected intestinal tracts (see above) of three +1 -and $-1-$ newborn mice each. Oligo (dT)primed CDNA was synthesized from the different RN A samples and used for the amplification of pancreatic mRNA sequences (25 cycles). Amplification reactions $(25 \mu \mathrm{l})$ contained mRN Aspecific oligonucleotide primers (50 pmoles each) and were incubated at the optimal annealing temperature (in parentheses) determined for each of the following primer combinations: p48 $\left(55^{\circ} \mathrm{C}\right)$, 5'-TGCAGTCCATCAACGACGC-3' (+) and 5'-GGACAGAGTTCTTCCAGTTC- $3^{\prime}(-) ; \alpha$-amylase $\left(60^{\circ} \mathrm{C}\right), 5^{\prime}$-CAGGCAATCCTGCAGGAACAA-3' (+) and 5'-CACTTGCGGATAACTGTGCCA-3' (-); carboxypeptidase A $\left(55^{\circ} \mathrm{C}\right)$, 5'-GCATCCATTCTAGGGAGTGG-3' (+) and 5'-GAAAGAGTACTTGATGCCCTG-3' (-); chymotrypsinogen B $\left(55^{\circ} \mathrm{C}\right)$, 5'-CATCCAGGTCCTGAAGATCG-3' (+) and 5'-CTGCCCCAGGACACAATGCC-3' (-); elastase I $\left(55^{\circ} \mathrm{C}\right)$, 5'-GTGGCTGCAGGCTATGACAT- $3^{\prime}(+)$, and 5'-GGTGAAGACTGTGGGCTTC-3' $(-)$;

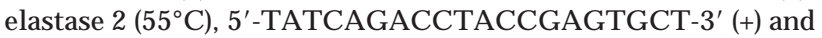
5'-ACACCATGCTGGACTTCACA-3' (-); trypsin 1 and trypsin $2\left(55^{\circ} \mathrm{C}\right), 5^{\prime}$-AGCACAACATCAATGTCCTGG-3' $(+)$ and $5^{\prime}-$ TGTATACACCAGGAGCATCTG-3' (-); Pdx-1 $\left(60^{\circ} \mathrm{C}\right), 5^{\prime}-\mathrm{GG}-$ ACCCGTACTGCCTACACC-3' (+) and 5'-GAGCCCAGGTTGTCTAAATTGG-3' (-); Beta-2 $\left(55^{\circ} \mathrm{C}\right)$, 5'-TGCAACTCAATCCTCGGACTT-3' (+) and 5'-CTCATGATGTGAATGGCTATC-3' (-); insulin I and insulin II $\left(55^{\circ} \mathrm{C}\right)$, 5'-CAGCCCTTAGTGACCAGCT- $3^{\prime}(+)$, 5'-CAGCCCTAAGTGATCCGCT-3' (+) and 5'-TGCTGGTGCAGCACTGATC-3' (-); ppp $\left(60^{\circ} \mathrm{C}\right)$, 5'AGGATGGCCGTCGCATACTG-3' (+) and 5'-GGCCTGGTCAGTGTGTTGATG-3' (-). Glucagon and somatostatin primers were those publ ished by Gittes and Rutter (1992). Isl-1 primers were taken from Jensen et al. (1996). All primers were chosen such that genomic DNA and unspliced pre-mRNA would amplify as larger fragments because of the presence of introns. PCR products were anayzed on $2 \%$ agarose gels and stained 
with ethidium bromide. Their origin was verified by restriction digestion or DN A sequencing. Amplification reactions containing CDN A made from mouse pancreas poly $(A)^{+}$RN A were done in parallel as a positive control and those in the presence of primers without CDNA as a negative control.

\section{RNA, DNA, and protein analysis}

The protocol for the isolation of RN A by the guanidinium thiocyanate method has been described previously (Schibler et al. 1980). Mouse tail DNA was extracted by use of the DNA extraction kit from Invitrogen. For Southern blot analysis, $10-\mu \mathrm{g}$ al iquots of EcoRI-digested DN A were separated on a $0.6 \%$ agarose gel. For N orthern blot analysis, $30 \mu \mathrm{g}$ of glyoxylated wholecell RN A was applied to each lane and fractionated on a $1.4 \%$ agarose gel. Filter-bound DNA and RN A were sequentially hybridized with the ${ }^{32} \mathrm{P}$-label ed probes indicated by use of standard procedures. Whole-cell protein was extracted from dissected tissue in a buffer containing $0.1 \mathrm{M} \mathrm{Tris-HCl}(\mathrm{pH} \mathrm{9.0),0.1 \%} \mathrm{Triton}$ $\mathrm{X}-100$, and the mixture of specific and nonspecific protease inhibitors described by Cockell et al. (1989). Western blot analysis was carried out essentially as described by Cockell et al. (1995). Five-microgram aliquots of protein were fractionated by SDSPAGE on a $10 \%$ gel. Protein was transferred from the gel to an Immobilon polyvinylidene difluoride filter and stained with Ponceau S dye (Fluka, Buchs, Switzerland). Filter-bound material was incubated first with a 1:3000 dilution of anti- $\alpha$-amylase antibody and then with goat anti-rabbit IgG-peroxidase conjugate (Sigma) for immunodetection of $\alpha$-amylase by ECL (Pierce, Rockford, IL).

\section{Acknowledgments}

We thank Dr. D.W. M elton for a generous gift of the HM-1 cell line and Drs. J. Tschopp, B. Lowin, E. Hummler and F. Beermann for their help and precious advice regarding cell culture. We also thank Drs. O. Madsen and $\mathrm{H}$. Edlund for the donation of antibodies and Dr. B. Thorens for the determination of blood insulin. We are greatly indebted to Dr. S. Falkmer who made us aware of important aspects of pancreas evolution. M.K. was supported by a fellowship of the Hertzfel der'sche Familien-Stiftung. This work was supported by a grant from the Swiss $\mathrm{Na}$ tional Science Foundation to P.K.W. and O.H. (no. 31-34027.93).

The publication costs of this article were defrayed in part by payment of page charges. This article must therefore be hereby marked 'advertisement' in accordance with 18 USC section 1734 solely to indicate this fact.

\section{References}

Ahlgren, U., J. Jonsson, and H. Edlund. 1996. The morphogenesis of the pancreatic mesenchyme is uncoupled from that of the pancreatic epithelium in IPF1/PDX1-deficient mice. De velopment 122: 1409-1416.

A hlgren, U., S.L. Pfaff, T.M. Jessell, T. Edlund, and H. Edlund. 1997. Independent requirement for ISL 1 in formation of pancreatic mesenchyme and islet cells. Nature 385: 257-260.

A pelqvist, A., U. A hlgren, and H. Edlund. 1997. Sonic hedgehog directs special ised mesoderm differentiation in the intestine and pancreas. Curr. Biol. 7: 801-804.

Birkedahl-Hansen, H. 1995. Proteolytic remodeling of extracelIular matrix. Curr. Opin. Cell Biol. 7: 728-735.

Bradley, A. 1987. Production and analysis of chimaeric mice. In Teratocarcinomas and embryonic stem cells: A practical approach (ed. E.J. Robertson), pp. 113-151. IRL Press, Oxford, UK.

Cirulli, V., D. Baetens, U. Rutishauser, P.A. Hal ban, L. Orci, and D.G. Rouiller. 1994. Expression of neural cell adhesion molecule (N-CAM) in rat islets and its role in islet cell type segregation. J. Cell Sci. 107: 1429-1436.

Cockell, M., B.J. Stevenson, M. Strubin, O. Hagenbüchle, and P.K. Wellauer. 1989. Identification of a cell-specific DNAbinding activity that interacts with a transcriptional activator of genes expressed in the acinar pancreas. Mol. Cell. Biol. 9: 2464-2476.

Cockell, M., D. Stolarczyk, S. Frutiger, G.J. Hughes, O. Hagenbüchle, and P.K. Wellauer. 1995. Binding sites for hepatocyte nuclear factor $3 \beta$ or $3 \alpha$ and pancreas transcription factor 1 are required for efficient transcription of the gene encoding pancreatic $\alpha$-amylase. Mol. Cell. Biol. 15: 1933-1941.

Dahl, U., A. Sjödin, and H. Semb. 1996. Cadherins regulate aggregation of pancreatic $\beta$ cells in vivo. Development 122: 2895-2902.

Falkmer, S. 1985. Comparative morphology of pancreatic isl ets in animals. In The diabetic pancreas (ed. B.W. Volk and K.F. Wellmann), pp. 17-52. Plenum Press, N ew York, NY.

Gavrieli, Y., Y. Sherman, and S.A. Ben-Sasson. 1992. Identification of programmed cell death in situ via specific labeling of nuclear DN A fragmentation. J. Cell Biol. 119: 493-501.

Gittes, G.K. and W.J. Rutter. 1992. Onset of cell-specific gene expression in the developing mouse pancreas. Proc. Natl. Acad. Sci. 89: 1128-1132.

Gittes, G.K., P.E. Galante, D. Hanahan, W.J. Rutter, and H.T. Debas. 1996. Lineage-specific morphogenesis in the devel oping pancreas: Role of mesenchymal factors. Development 122: 439-447.

Gupta, S., J.M. Wilson, and J.R. Chowdhury. 1992. Hepatocyte transplantation: development of new systems for liver repopulation and gene therapy. Sem. Liver disease 12: 321331.

Guz, Y., M.R. Montminy, R. Stein, J. Leonard, L.W. Gamer, C.V.E. Wright, and G. Teitelman. 1995. Expression of murine STF-1, a putative insulin gene transcription factor, in $\beta$ cells of pancreas, duodenal epithelium and pancreatic exocrine and endocrine progenitors during ontogeny. Development 121: 11-18.

Hebrok, M. S.M. Kim, and D.A. Melton. 1997. N otochord repression of endodermal Sonic hedgehog permits pancreas development. Genes \& Dev. 12: 1705-1713.

Hutton, J.C., G. Christofori, W.Y. Chi, U. Edman, P.C. Guest, D. Hanahan, and R.B. Kelly. 1993. Molecular cloning of mouse pancreatic islet R-cadherin: Differential expression in endocrineand exocrine tissue. Mol. Endocrinol. 7: 11511160.

Jensen, J., P. Serup, C. Karlsen, T.F. N ielsen, and O.D. M adsen. 1996. mRN A profiling of rat islet tumors reveals $\mathrm{N} \mathrm{kx} 6.1$ as a $\beta$-cell-specific homeodomain transcription factor. J. Biol. Chem. 271: 18749-18758.

Jonsson, J., L. Carlson, T. Edlund, and H. Edlund. 1994. Insulinpromoter-factor 1 is required for pancreas development in mice. Nature 371: 606-609.

Karlsson, O., S. Thor, T. N orberg, H. Ohlsson, and H. Edlund. 1990. Insulin gene enhancer protein IsI-1 is a member of a novel class of proteins containing both a homeo- and a CysHis domain. Nature 344: 879-882.

Kim, S.K., M. Hebrok, and D.A. Melton. 1997. N otochord to endoderm signaling is required for pancreas development. Development 124: 4243-4252.

Knöfler, M., A. Krapp, O. Hagenbüchle, and P.K. Wellauer. 1996. Constitutive expression of the gene for the cell-specific p48 
DNA-binding subunit of pancreas transcription factor 1 in cultured cells is under control of binding sites for transcription factors Spl and $\alpha$ CBF. J. Biol. Chem. 271: 21993-22002.

Krapp, A., M. Knöfler, S. Frutiger, G.J. Hughes, O. Hagenbüchle, and P.K. Wellauer. 1996. The p48 DNA-binding subunit of transcription factor PTF1 is a new exocrine pancreas-specific basic helix-loop-helix protein. EMBO J. 15: 4317-4329.

Laird, P.W., A. Zijderveld, K. Linders, M.A. Rudnicki, R. Jaenisch, and A. Berns. 1991. Simplified mammalian DNA isolation procedure. Nucleic Acids. Res. 19: 4293.

Larsson, L.-I., O.D. M adsen, P. Serup, J. Jonsson, and H. Edlund. 1996. Pancreatic-duodenal homeobox 1-role in gastric endocrine patterning. Mech. Dev. 60: 175-184.

Le Douarin, N.M. 1988. On the origin of pancreatic endocrine cells. Cell 53: 169-171.

Leonard, J., B. Peers, T. Johnson, K. Ferreri, S. Lee, and M.R. M ontminy. 1993. Characterization of somatostatin transactivating factor-1, a novel homeobox factor that stimulates somatostatin expression in pancreatic islet cells. Mol. Endocrinol. 7: 1275-1283.

Magin, T.M., J. McWhir, and D.W. Melton.1992. A new mouse embryonic stem cell line with good germ line contribution and gene targeting frequency. Nucleic Acids. Res. 20: 37953796.

Miller, C.P., R.E. McGehee, and J.F. Habener. 1994. IDX-1: A new homeodomain transcription factor expressed in rat pancreatic islets and duodenum that transactivates the somatostatin gene. EMBO J. 13: 1145-1158.

Moller, C.J., S. Christgau, M.R.Williamson, O.D. Madsen, N. Zhan-Po, E. Bock, and S. Baekkeskov. 1992. Differential expression of neural cell adhesion molecule and cadherins in pancreatic islets, glucagonomas, and insulinomas. Mol. Endocrinol. 8: 1332-1342.

Naya, F.J., C.M.M. Stellrecht, and M.-J. Tsai. 1995. Tissue specific regulation of the insulin gene by a novel basic hel ix loop helix transcription factor. Genes \& Dev. 9: 1009-1019.

Naya, F.J., H.-P. Huang, Y. Qiu, H. Mutoh, F.J. DeM ayo, A.B. Leiter, and M.-J. Tsai. 1997. Diabetes, defective pancreatic morphogenesis, and abnormal enteroendocrine differentiation in BETA2/NeuroD-deficient mice. Genes \& Dev. 11: 2323-2334.

Nose, A., A. N agafuchi, and M. Takeichi. 1988. Expressed recombinant cadherins mediate cell sorting in model systems. Cell 54: 993-1001.

N ose, A., K. Tsuji, and M. Takeichi. 1990. Localization of specificity determining sites in cadherin cell adhesion molecules. Cell 61: 147-155.

Offield, M.F., T.L. Jetton, P.A. Labosky, M. Ray, R.W. Stein, M.A. Magnuson, B.L.M. Hogan, and C.V.E. Wright. 1996. PDX-1 is required for pancreatic outgrowth and differentiation of the rostral duodenum. Development 122: 983-995.

Ohlsson, H., K. Karlsson, and T. Edlund. 1993. IPF1, a homeodomain containing transactivator of the insulin gene. EMBO J. 12: 4251-4259.

Petrucco, S., P.K. Wellauer, and O. Hagenbüchle. 1990. The DNA-binding activity of transcription factor PTF1 parallels the synthesis of pancreas-specific mRN As during mouse development. Mol. Cell. Biol. 10: 254-264.

Pictet, R. and W.J. Rutter. 1972. Development of the embryonic endocrine pancreas. In Handbook of physiology (ed. D.F. Steiner and N. Frenkel), vol. 1, pp. 25-66. Williams and Wilkins, Baltimore, MD.

Roux, E., M. Strubin, O. Hagenbüchle, and P.K. Wellauer. 1989. The cell-specific transcription factor PTF1 contains two different subunits that interact with the DNA. Genes \& Dev. 3: 1613-1624.
Schibler, U., M. Tosi, A.C. Pittet, L. Fabiani, and P.K. Wellauer. 1980. Tissue-specific expression of mouse alpha-amylase genes. J. Mol. Biol. 142: 93-116.

Sjödin, A., U. Dahl, and H. Semb. 1995. M ouse R-cadherin: Expression during the organogenesis of pancreas and gastrointestinal tract. Exp. Cell Res. 221: 413-425.

Sommer, L., O. Hagenbüchle, P.K. Wellauer, and M. Strubin. 1991. N uclear targeting of the transcription factor PTF1 is mediated by a protein subunit that does not bind to the PTF1 cognate sequence. Cell 67: 987-994.

Spooner, B.S., B.T. Walther, and W.J. Rutter. 1970. The development of the dorsal and ventral pancreas in vivo and in vitro. J. Cell Biol. 47: 235-246.

Sosa-Pineda, B., K. Chowdhury, M. Torres, G. Oliver, and P. Gruss. 1997. The Pax4 gene is essential for differentiation of insulin-producing $\beta$ cells in the mammalian pancreas. Nature 386: 399-402.

St-Onge, L., B. Sosa-Pineda, K. Chowdhury, A. M ansouri, and P. Gruss. 1997. Pax6 is required for differentiation of glucagonproducing $\alpha$-cells in mouse pancreas. Nature 387: 406-409.

Volk, T., O. Cohen, and B. Geiger. 1987. Formation of heterogenic adherens type junctions between L-CAM containing liver cells and A-CAM containing lens cells. Cell 50: 987994.

Wang, M. and D.J. Drucker. 1995. The LIM domain homeobox gene isl-1 is a positive regulator of islet cell-specific proglucagon gene transcription. J. Biol. Chem. 270: 12646-12652.

Wessells, N.K. and J.H. Cohen. 1967. Early pancreas organogenesis: Morphogenesis, tissue interactions and mass effects. Dev. Biol. 15: 237-270.

Wright, C.V.E., P. Schnegelsberg, and E.M. De Robertis. 1988. XIHbox8: A novel Xenopus homeo protein restricted to a narrow band of endoderm. Development 104: 787-794. 


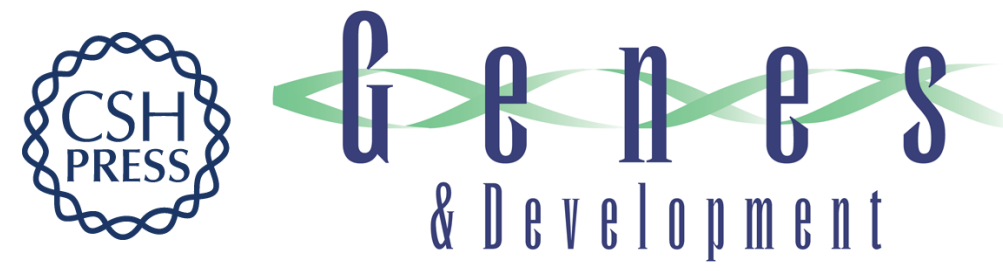

\section{The bHLH protein PTF1-p48 is essential for the formation of the exocrine and the correct spatial organization of the endocrine pancreas}

Andrea Krapp, Martin Knöfler, Birgit Ledermann, et al.

Genes Dev. 1998, 12:

Access the most recent version at doi:10.1101/gad.12.23.3752

\section{License}

Email Alerting Receive free email alerts when new articles cite this article - sign up in the box at the top Service right corner of the article or click here.

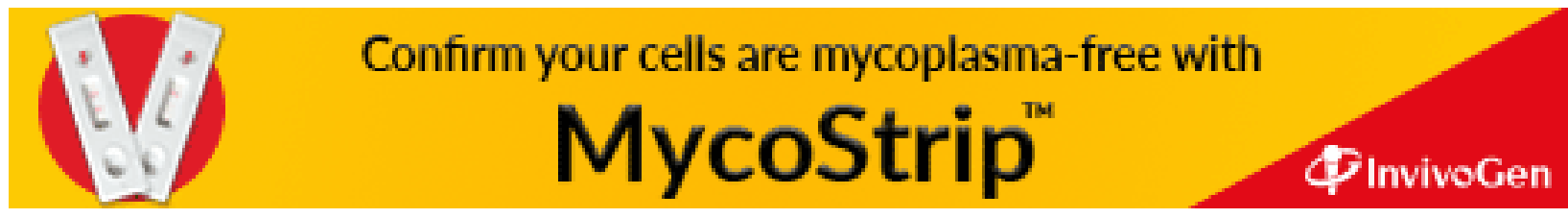

